\title{
GEOGRAPHY AT THE UNIVERSITY OF WARSAW
}

Before we introduce our readers to a successive volume of Miscellanea Geographica it would be useful to return to the article on geography at the University of Warsaw published four years ago $^{1}$ to supplement and update its contents.

The Faculty of Geography and Regional Studies, with its Dean, Professor Andrzej Richling since 1984 (Deputy Deans: W. Grygorenko, S. Komorowski, A. Kostrowicka in the years 1984-1987, and S. Otok, F. Plit and M. Stopa-Boryczka since 1987) consists of Institutes and Departments which are currently focused on the following research and teaching activities:

\section{INSTITUTE OF PHYSICAL GEOGRAPHY (Dir. U. Soczyńska)}

Department of Complex Physical Geography (A. Richling), including the Chair of Geochemistry of Landscape, carries out complex research on nature approached as a system of mutually interdependent components; delimitation of geocomplexes as the reference basis in physico-geographic studies and in studies on the "man-environment" interaction.

Laboratory of Sedimentology (E. Dowgiałlo): studies on the structure and texture of sediments to define the origin and evolution of refief as well as dynamics of relief-forming processes; the dating of sediments by the thermoluminescent method. The main aim is to train specialists in natural resources management and prepare them for work in planning and organizations dealing with environmental management and protection.

Department of Geomorphology (M. Bogacki): is involved in studies on the origin and evolution of relief, on modern morphological processes in various morphological zones and on the role of anthropopressure in transformation of relief as well as synthetic approaches (survey maps) to modern morphogenesis. The aim of training is to develop theoretical and practical capabilities required for unaided conduct of research in the field of geomorphology. The focus is on modern research methods applicable in environmental management and protection, as well as in organizations involved in geological, physiographic, cartographic, planning, etc. institutions. 
Department of Climatology (M. Stopa-Boryczka) : research on climate changes and fluctuations in moderate zones on the example of Poland, effect of geographical factors on the fields of meteorological variables, and deformation of fields of metorological variables by a built-up area. A graduate majoring in climatology should know the processes arising in the atmosphere and in boundary strata, the relations between climate and other elements of geographical environment, the relevant field of research (i.a. microclimatic observations), and the interpretation of the results thus obtained. This knowledge should enable him to cope with the problems related to spatial planning, management and protection of environment.

Department of Hydrology (Z. Mikulski): parametrization of geographical environment for the mathematical modelling of hydrological processes; balancing of water resources and the investigation of their spatial and time variability; studies on the effect of man's activity on the hydrological regime and water quality with special reference to the effect of urbanization and industrialization.

The graduate should acquire general education in natural science with the stress laid on problems of water circulation in the environment. The graduate must be prepared theoretically and practically, i.e. for the hydrometorological fieldwork.

INSTITUTE OF SOCIAL, ECONOMIC AND REGIONAL GEOGRAPHY

(Dir. W. Kusiński)

Department of Economic Geography (W. Kusiński): research on spatial structure of population distribution and settlement as well as of agriculture and industry, especially areas of central and north-east Poland (mainly of the Warsaw suburban zone). The graduate is supposed to work in planning and economic institutions or as a teacher in primary and secondary schools. Thus the focus is on the knowledge of the economy's structure and its spatial organization (population, settlement system, resources, agriculture, manufacturing industries, transport, tourism, social and economic infrastructure) as well as on the ability to gather and process the relevant information.

Department of Regional Geography (B. Dumanowski): research on the relationship between man's activity and natural environment, particularly on the effect of natural barriers and boundaries, differentiation of natural environment, and border conditions; searching for methods of a synthetic evaluation of these relationships. The focus is to give the graduate the knowledge of problems and research methods of the relations between man's activities and natural conditions. The emphasis is laid on the synthetic approach to socio-economic global and regional development problems.

Department of Social Geography (S. Otok): research on spatial differentiation of social processes; natural environment in Poland's social policy; 
studies on the Polish abroad; geography of social threats; problems of political consistency of states. The focus is on problems and research methods of relations between the society and the geographical environment. The graduate should be well acquainted with the approaches to social and political problems in spatial context; he is expected to work in planning, political and cultural institutions, both at local and central levels, as well as in scientific research.

Department of Teaching of Geography (A. Kostrowicka): research on the education of teachers of geography; studies on curricula, methods and problems related to the teaching of geography. The aim is to prepare teachers of geography for all types of schools.

\section{INSTITUTE OF DEVELOPING COUNTRIES (Dir. B. Winid)}

Department of Economic Development (Z. Dobrska): the analysis of development strategies and distribution of income in developing countries, and, today, particularly of problems of debt and methods of adaptation of economies of these countries to different relations of world market.

Department of Political and Legal Studies (J. J. Milewski): research on transformation of political systems and ruling elites; conflicts and wars between the developing countries, rise of the so-called right to development in international law, place of women in economic, social and political life.

Department of Regional Comparative Research (F. Plit): problems of spatial management in Africa and Latin America with special reference to population problems (urbanization, role of towns) and natural conditions for development in unfavourable environment.

Department of Social Development (Z. Komorowski): problems of ethnic geography and cultural anthropology of the selected groups; studies on cultures and their influence on social life, urbanization and modernization of rural areas; problems of sociology of education and science.

\section{INSTITUTE OF SPACE ECONOMY (Dir. A. Kukliński)}

Regional development - local development - territorial self-government, processes of overcoming crisis in Poland's spatial economy, perception and evaluation of natural and anthropological environment, space organization in history and future forecasts (world studies on regional development), methodology of interdisciplinary regional studies. Graduates are taught in theoretical and practice-oriented directions. Besides general geographical theoretical and empirical knowledge, they are provided with sound foundations in mathematics and statistics, methods of spatial analysis, systems theory and approach, management and organization principles as well as with the foundations of computer science. They also have the 
knowledge of economic, sociological and political problems of Poland and contemporary world.

\section{CHAIR OF CARTOGRAPHY, INCLUDING PHOTOINTERPRETATION AND REMOTE SENSING (W. Grygorenko)}

General theory of cartography, theory of cartographic transmission, knowledge of maps, cartographic -methodology as well as teledetection and photointerpretation. The graduate, besides general geographical knowledge, should have a thorough knowledge of theory of cartographic communication, advanced map design and technique of map production.

\section{MAZOVIAN GEOGRAPHICAL OBSERVATORY (W. Lenart)}

It is located at Murzynowo village (Plock voivodship) on the high bank of the Vistula river. It conducts research and teaching activities in meteorology, hydrology, geomorphology, climatology, geochemistry and environmental protection. These studies are conducted by the Observatory's staff, Faculty's staff on temporary assignment, Faculty's students and visiting scholars. The research is focused on dynamics of environmental transformations in the zone of rapidly developing urban complex of Plock. This requires numerous permanent, periodical and experimental field measurement facilities. With this purpose, the Observatory operates two meteorological stations, evaporimetric range, pluviometric range, research drainage basins (subject to anthropopressure), and an experimental drainage basin for investigations on water circulation and identification of its physico-geographical parameters and other field installations. The Observatory has geochemical and sedimentological laboratories, apparatus workshop, as well as computer, polygraphic and other facilities.

In the above-mentioned departments there are two years' specialization studies after three years of general studies. Apart from five-year studies, the Faculty also conducts postgraduate studies for specialists on developing countries, for specialists in environmental management (organized jointly with the Faculty of Biology) and for teachers of geography. The Faculty also conducts doctoral studies. This is facilitated by a proper base, mainly the Central Geographical Library - a joint venture of the Institute of Geography and Space Economy of the Polish Academy of Sciences and the Faculty of Geography and Regional Studies of Warsaw University, both located in the same building. This is the largest geographical library in Poland: it comprises more than 210,000 volumes, more than 4,000 atlases, some 165,000 maps, and 40,000 diapositives.

The pattern of research organization is strongly influenced by the centrally financed State research system that follows the long-term programming; it is, however. flexible enough to accommodate current demand 
for research gencrated by various State bodies and organizations. These programmes represent the majority of the Faculty's research activities.

The most important of these programmes is the all-Poland programme "Regional development - local development -- territorial self-governance", coordinated since 1986 by the Institute of Space Economy (Professor A. Kuklinski), preceded with research on diagnosis of the state of spatial economy of Poland. The programme is carried out in the following groups: methodology of research and theoretical generalization, political problems of the functioning of local authority, problems of the functioning of local authority and territorial seif-government, sociological problems of the functioning of local communities, local economy, monographic studies on a local scale, scenarios, experiments and practical applications. Other topics sponsored from outside and carried out at our Faculty include i.a.:

- Natural Development of the Social Policy of the State (drinking water supply as a measure of the living standard of population, social consequences of environmental hasards, aesthetics of landscape as a social identification of inhabitants);

- Conditions for development of developing countries (economic utilization, role of State, barriers to management);

- Processes of overcoming crisis in spatial economy of Poland;

- Spatial differentiation of social pathology;

- Transformation of environment in the zone of influence of urban and industrial complexes;

- Methods of analysis and utilization of water basins;

- Changes in water balance of Poland;

- Perception and evaluation of environment;

- Research on structure and dynamics of geo-complexes;

- Typology and utiiization of landscapes.

Most of these programmes are multidisciplinary.

Results of research are published in occasional publications and in regular publications, including:

-- Prace i Studia Geograficzne (Geographical Works and Studies), in Polish with abstracts in foreign languages;

- Miscellanea Geographica, in English, French and Spanish;

-- Africana Bulletin, in English and French;

- Afryka, Azja, Ameryka Lacińska, in Polish;

-.- Actas Latinoamericanas, in Spanish.

The publications permit a wide exchange of materials with foreign countries, which constitutes one of the elements of fruitful cooperation. The exchange is carried out by various channels: from individual visits through traditional regular bilateral seminars, joint elaborations and students' exchange (for example, Polish-Chechoslovakian seminars, research on methodology of elaboration of landscape maps as well as the influence of water basins on the hydrological regime and water quality in cooperation 
with the University of Sofia, Bulgaria, exchange with the Komonosow University in Moscow), participation in international research projects (for example, in the UNESCO International Hydrological Programme and in International Association for Landscape Ecology; in the programme "Development Experiences and Prospects", launched by the European Economic Commission; in the CMEA programmes on consequences of territorial transformation of natural systems, evaluation of the society's effect on environment as well as ecological foundations of landscape management and planning; in research on scarsely populated areas in collaboration with Scandinavian countries and Canada; in teledetection studies of the programme "INTERKOSMOS" of the CMEA) to cooperation under some official arrangements, including:

- an agreement with the University of Montpellier (i.a. yearly joint fieldwork and publications on "Valeur de l'espace et développement local"),

- an agreement with Escuela de Geografia de la Universidad Autonoma del Estado de Méjico in Toluca (joint seminars every second year and fieldwork),

- an agreement with the University of Sussex,

- an agreement with the Faculty of Environmental Studies of the University of Waterloo, Canada. 